\title{
6. Reforms and new challenges for work and employment in France: Social dialogue under pressure
}

\section{Christine Erhel}

\section{INTRODUCTION}

French social dialogue institutions are well developed at their various levels, from the company to the sectoral and national. Social partners benefit from important rights and protections, and their contribution to the general interest is recognized through their participation in the administration of workers' rights, from social protection to training and employment tribunals. The state also continues to play a crucial role in French industrial relations, however: the government sets the minimum wage, important rights and regulations are determined by law, as are some compulsory matters for company-level bargaining, and the Ministry of Labour extends almost all sectoral agreements.

That system has performed well, and in particular seems to have prevented a rise in inequalities and poverty of the type characteristic of liberal market economies (Courtioux and Erhel 2018). It also helps to protect workers' rights in a context of accelerated technological change and digitalization, which are leading to job destruction for some routine occupations and far-reaching changes in the nature of work and working conditions (COE 2017). French social dialogue institutions have also been subject to many criticisms, however, from a number of viewpoints. From a market liberal standpoint, the lack of flexibility at the company level resulting from the centralized model can reduce firms' capacity to adapt to changing conditions and, therefore, be detrimental to their competitiveness and contribute to higher unemployment. In addition, within the framework of the insider-outsider model, some economists also consider that the French system protects insiders rather than offers opportunities to new labour market entrants, and therefore favours labour market dualism. Workers on flexible contracts (temporary contracts, temporary agency work and part-time jobs), as well as the self-employed (including those working for platforms) would be disadvantaged. Criticisms also focus on trade unions' lack of representativeness in a context of low membership rates and low confidence expressed by employees (or the public more generally) in numerous opinion surveys.

In a context of strikes and protests against projects to reform the pension system at the end of 2019, and following the gilets jaunes social movement that started in autumn 2018, protesting against petrol prices and environmental taxes, the social climate appears conflictual. The social partners are under pressure, both from public opinion (the movement of the gilets jaunes started through social networks and was not controlled nor influenced by the unions) and from the government. Pressure also comes from the reforms currently 
being implemented, dealing with workers' representation at the company level and decentralization of collective bargaining, but also further training, unemployment insurance and pensions.

This chapter discusses the capacity of the social partners to define and influence labour market regulations in a new labour market context, as well as their autonomy at the sectoral and company level, taking into account the recent reforms of social dialogue and collective bargaining. At the micro level, it also analyses the situation of employee representatives and employees' perceptions, which is a crucial issue for trade union influence. Although institutionalized social dialogue processes and the role of the social partners are at the core of our analysis, we consider a broad definition of social dialogue, including informal forms of social dialogue, and the different levels at which social dialogue may take place: the national, regional and enterprise levels, and the inter-sectoral or sectoral dimensions.

Section 2 presents an overview of the institutions of social dialogue and discusses the issue of representativeness and the recent trends in the role of the different bargaining levels. Section 3 focuses on recent reforms and their effects to date on social partners' capacities and autonomy. Section 4 adopts a micro-level viewpoint to describe the actors of company-level social dialogue, and discuss employees' perceptions. Section 5 concludes by noting the main issues for the social partners. Two case studies address important issues for the French model. The first (section 6) concerns the extension of collective agreements, which plays a key role in equalizing employment and working conditions across sectors, and discusses its recent evolution and potential tensions for the future. The second (section 7) focuses on the way company collective agreements and bargaining processes deal with the issue of digitalization.

\section{SOCIAL DIALOGUE IN FRANCE: REPRESENTATIVENESS OF SOCIAL PARTNERS AND DYNAMICS OF MULTI-LEVEL BARGAINING}

Institutionalized social dialogue in France relies first on trade unions and employers' organizations, which discuss and bargain at several levels: national, inter-sectoral, regional or local, sectoral and firm levels. However, within firms, it also involves other elected actors, representing employees, who have a consultation and information role, but also, in some cases, a capacity to negotiate. ${ }^{1}$

\subsection{Social Partners in France and Representativeness Issues}

In France in 2019 there are eight active trade unions at the national level (CFDT, CGT, FO, CFE-CGC, CFTC, FSU, SUD-Solidaires and UNSA), ${ }^{2}$ five of which are considered representative at the national and inter-sectoral level (CFDT, CGT, FO, CFE-CGC and CFTC). On the employers' side, there are numerous employers' organizations, three of which are representative (CPME, MEDEF and U2P). ${ }^{3}$

Until 2008, and since the Second World War, the French industrial relations system was subject to the presumption of representativeness: representative trade unions were designated by the state, based on a number of criteria (political values, autonomy, 
financial transparency, influence and number of members). For employers' organizations, representativeness resulted from mutual recognition between federations (Langevin 2019). The objective of recent policies has been to reinforce the social partners' legitimacy and, therefore, to assess their representativeness using objective criteria: elections for trade unions and membership for employers' organizations.

Since 2008, unions must achieve at least 10 per cent of the votes at company level and 8 per cent of votes at sectoral or national multi-sectoral level (in elections) to be considered representative. Elections were organized in 2013 and 2017, in which the five traditional unions maintained their position at the national level (see Table 6.1), but not in all sectors, whereas two smaller unions have been enabled to set up in some sectors, which promoted multiple union representation at the sectoral level. Workers' participation in these elections is substantial (41.6 per cent in 2017), although it has been decreasing since 2013. In the public sector, representativeness rules are different and UNSA, Solidaires and FSU are also representative, in addition to the five historical unions.

Concerning the employers' federations, an Act of $2014^{4}$ introduced a rule for measuring representativeness using membership data, which became effective in 2017: a federation is representative if it covers at least 8 per cent of companies or 8 per cent of employees. In practice, three employers' federations meet that criterion and were declared representative by the Ministry of Labour in June 2017 (Table 6.2).

The unionization rate is low in France: on average, it amounted to 10.8 per cent in 2016, which is among the lowest rates among Organisation for Economic Co-operation and Development (OECD) countries. However, despite some uncertainty about estimation, ${ }^{5}$ it appears to have been relatively stable since the early 1990 s, after two phases of important decline (between 1950 and 1960, and between 1975 and 1990; see Figure 6.1).

Unionization is traditionally higher in the public sector (18.7 per cent in 2016), and especially in education and the police, than in the private sector ( 8.4 per cent $){ }^{6}$

Table 6.1 Trade unions at the national level, France, 2017-18

\begin{tabular}{lccc}
\hline & $\begin{array}{c}\text { Votes private } \\
\text { sector 2017 }(\%)\end{array}$ & $\begin{array}{c}\text { Votes public } \\
\text { sector 2018 }(\%)\end{array}$ & $\begin{array}{c}\text { Aggregate level public and } \\
\text { private sectors (\% votes) }\end{array}$ \\
\hline CFDT & 26.4 & 19.0 & 24.0 \\
CGT & 24.8 & 21.8 & 23.9 \\
FO & 15.6 & 18.1 & 16.4 \\
CFE-CGC & 10.7 & 3.4 & 8.4 \\
CFTC & 9.5 & 2.9 & 7.4 \\
UNSA & 5.4 & 11.2 & 7.2 \\
Solidaires & 3.5 & 6.4 & 4.4 \\
Others & 4 & 17.2 & 8.3 \\
\hline
\end{tabular}

Note: First column comprises representative trade unions at the national level (over the 8 per cent threshold) in the private sector.

Source: Direction Générale du Travail, Gazier and Petit (2019), Direction générale de l'Administration et de la Fonction publique (DGAFP). 
Table 6.2 Employers' organizations at the national level, France, 2017 (percentage represented)

\begin{tabular}{lcc}
\hline & Firms & Employees \\
\hline MEDEF & 29.4 & 70.7 \\
CPME & 34.5 & 25.0 \\
U2P & 35.9 & 4.2 \\
\hline
\end{tabular}

Source: Direction Générale du Travail, Gazier and Petit (2019).

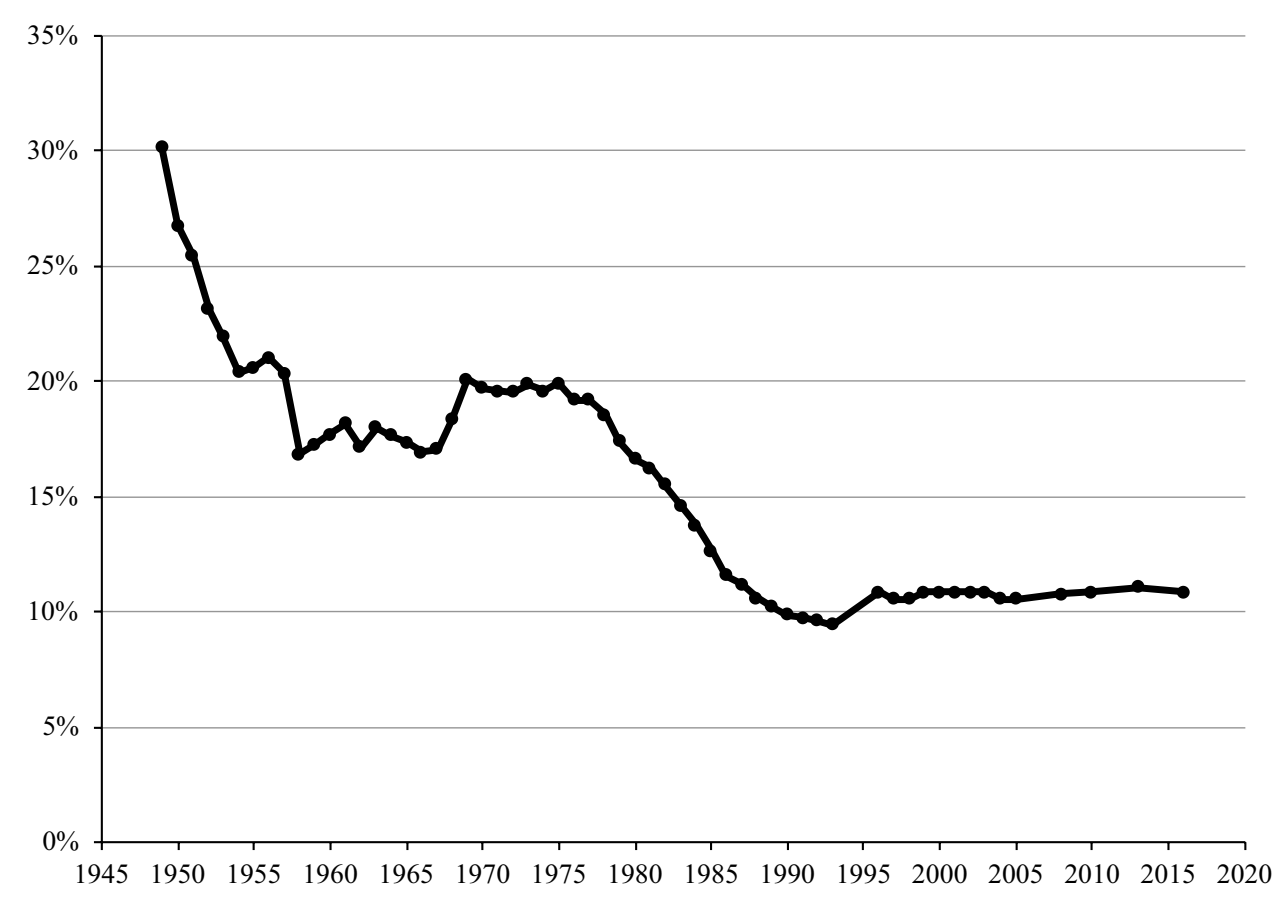

Source: DARES, Pignoni (2016).

Figure 6.1 Unionization rate: share of workers (aged 15 years and more) who are trade union members (percentage)

Within the private sector, unionization rises with firm size, and appears to be higher in manufacturing and transport than in services. As regards individual characteristics, men are more likely than women to be member of a union (11.8 per cent compared with 9.8 per cent, respectively), and the unionization rate rises with age (from 3.6 per cent for younger workers, aged under 30 , to 14.6 per cent for those aged over 50). Differences by occupation are limited, but the lowest rates are among manual workers (9.6 per cent, compared with 11 per cent for managers and professionals). Interestingly, union membership clearly relates to employment status, and to job stability: less than 2 per cent of temporary agency workers and temporary contract workers are unionized. These figures 
(as well as union members' age profile) indicate a deficit in the protection of vulnerable workers, who are the main victims of atypical and unstable employment.

Union membership cannot be considered a good measure of union power in France, however, as collective agreements apply to non-members and sectoral agreements are generally extended to all firms and workers in the sector, which results in a very high coverage rate (over 95 per cent). Besides, unions (and employers' organizations) participate in defining and managing social and training policies (unemployment insurance, retirement, further training) and receive some public financing in exchange for this role.

\subsection{At the Firm Level: Dual Employee Representation}

At the firm level, employee representation is dual: it involves both elected staff representatives and trade union delegates (appointed by trade unions ${ }^{7}$ ). Elected staff representatives have rights in relation to information and consultation, whereas union delegates are entitled to participate in firm-level collective bargaining. Since 2019, there has been a single institution for elected staff representatives, the social and economic committee (Comité Social et Economique, CSE), for all firms with more than 11 employees. That single committee replaces the three institutions that previously existed: ${ }^{8}$ worker delegates (représentants $d u$ personnel, compulsory for firms with more than 11 employees), works council (comité d'entreprise, CE, compulsory when over 50 employees), and health and safety committee (Comité d'Hygiène, de Sécurité et des Conditions de Travail, CHSCT, compulsory when over 50 employees). Employee representation based on these two types of representation has been growing over time. As a consequence, in 2017, 67 per cent of workplaces with more than 11 employees (and almost all workplaces with over 100 employees) had at least one type of employee representative, and 37 per cent at least one trade union delegate. This corresponds to 86 per cent of employees covered by at least one employee representative, and 64 per cent covered by at least one trade union delegate (Romans 2018).

This employee representation is clearly related to firm size, given the existence of legal thresholds by size (see Figure 6.2). Under 11 employees, firms do not have to organize elections and designate worker representatives, so that social dialogue remains mostly informal. Data by firm size (rather than workplace size, based on an ACEMO survey) show more clearly the low coverage of small and medium-sized firms: in 2012, 78 per cent of firms with between 10 and 19 employees had no employee representative, whereas this was so in only 5 per cent of firms with over 100 employees.

\subsection{A Fairly Dynamic Multi-level Collective Bargaining System}

Collective bargaining takes place at three main levels in France: national and intersectoral level, sectoral level and company level, but it may also be organized at the local level (for a given territory). Historically, below the national level, the sector has been the prevailing level, but company-level bargaining has been compulsory since 1982 (for firms over 50 employees with one union delegate), and has been constantly extended since then.

In this multi-level system, the law has to define the relationships between the different levels. The traditional model of French labour law (Code du travail) was based on two key principles: hierarchy between standards (legislation and regulation $>$ agreements and 


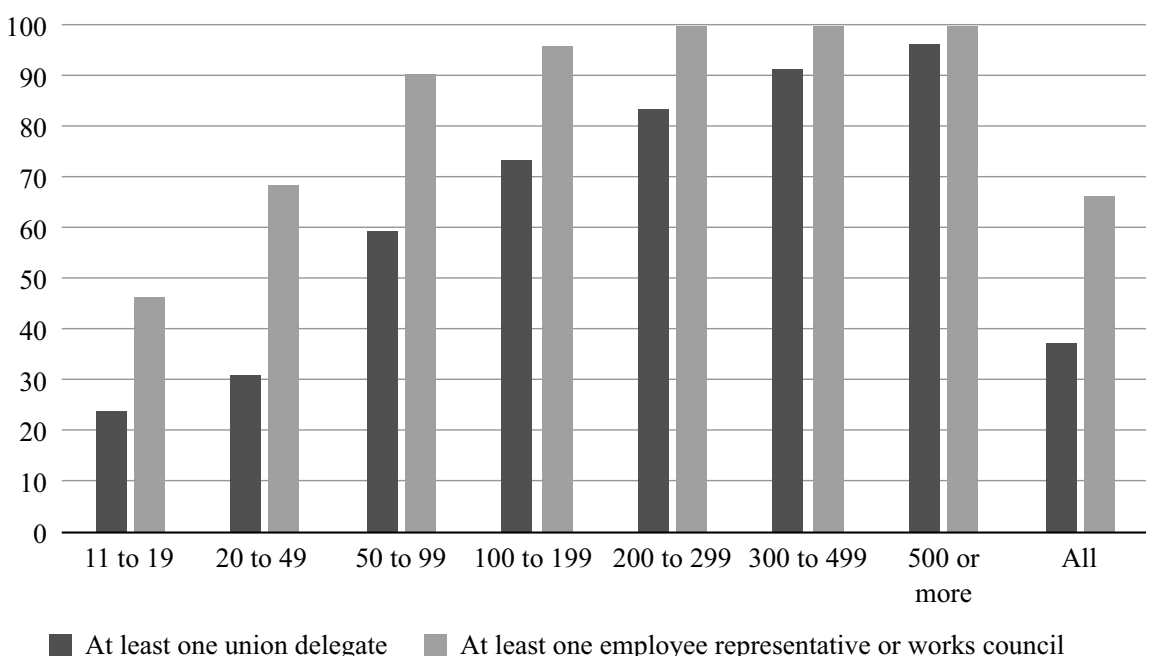

Source: DARES, REPONSE 2017, Romans (2018).

Figure 6.2 Coverage of firms by representative bodies of staff in 2017

national multi-sectoral agreements $>$ sectoral agreements $>$ company level agreements) and the favourability rule (core workplace guarantees/ordre public social) which implies that a lower-ranking rule can only take precedence over a higher-ranking rule if it is more beneficial to the employee. This model generally applied until 2016, although there was some evolution as early as 2004 and 2008 (for instance, concerning working time).

The Labour Act $(2016)^{9}$ reformed the hierarchy between standards, establishing the pre-eminence of company agreements on the issues of working time and employment maintenance. In accordance with a previous inter-sectoral agreement of $2013,{ }^{10}$ employment maintenance agreements take precedence even over individual labour contracts, including wages (the monthly wage is still guaranteed but flexible pay and premiums can be adjusted) and working time. If employees refuse to accept the new rules, they can be dismissed. In the face of trade union resistance and public opinion, however, the government finally laid down that a number of important topics constitute 'fundamental issues' in relation to which company agreements cannot undercut sectoral agreements: minimum wages, occupational classifications, private social protection, vocational training, gender equality and hard or dangerous working conditions (pénibilité).

The September 2017, ordinances slightly modified these rules. Sectoral agreements prevail for minimum wages, occupational classifications, vocational training, private social protection and gender equality, but also for job quality standards and labour contract conditions (part-time contracts and fixed-term contracts). For a few other topics (hard working conditions and disability) the relevant sector will decide whether sectoral agreements will prevail over firm-level agreements, but the general rule is in favour of the latter.

In order to develop collective bargaining in firms where there is no trade union delegate, the law has provided possibilities to sign an agreement with elected employee delegates or employees mandated by a union. In the absence of delegates, the agreement has to be 
validated by a majority of workers, through a referendum. For firms of 50 employees or more, employers can bargain only with an employee mandated by a union. In small firms (fewer than 11 employees, or between 11 and 20 employees if there was no candidate in staff elections), the 2017 ordinances have also opened up the possibility for employers to submit an agreement directly to employees, through a referendum. This must be validated by two-thirds of employees.

In practice, bargaining activity is important at company and sectoral levels. A total of 1288 agreements were signed in 2018 at the sectoral level, slightly above the number in 2017 (1166). At the firm level, the number of agreements signed in 2018 was around 75600 , among which 51.7 per cent were signed by unions, 13 per cent by other staff representatives and 21 per cent were validated directly by employees. These company-level agreements mainly concern earnings (wage and non-wage) and working time, whereas sectoral agreements deal with wages, but also gender equality, training and apprenticeship (DGT 2019).

The situation with small firms is specific: social dialogue is mainly informal and is rarely transposed into an agreement. Even if it is difficult to obtain information on these informal processes, it seems that employee participation remains limited. A 2016 survey by the Ministry of Labour focused on social dialogue in firms with fewer than 10 employees, and showed that 80 per cent of them declared that they had taken decisions on wages, employment, working conditions or working time in 2016. Employees were collectively involved in these decisions in 31 per cent of these firms (Tall 2018).

In summary, the low unionization rate, as well as the large number of unions with few members, indicate the fragility of the French trade unions (in relation to funding and autonomy, but also the coverage of different types of workers, including the most precarious), but it does not fully represent the reality of unions' role and influence, as their presence at company level is important (through staff elections and union delegates), except in small firms. Recent reforms have tried to reinforce legal representativeness by relating it to the results of staff elections (and membership for employers' organizations), and to create incentives for more decentralized collective bargaining. They have also introduced mechanisms for concluding agreements without unions in small firms, which does not help to reinforce unions.

\section{STRENGTHENING SOCIAL DIALOGUE AND CAPACITY TO ADAPT TO THE NEW WORLD OF WORK: AMBITIOUS REFORMS AND ACTORS' PERCEPTIONS}

In this section, we analyse recent laws reforming social dialogue and collective bargaining, the ambition of which is to reinforce and modernize social dialogue to face the new challenges of the world of work, based on interviews and initial evaluation reports on the 2017 labour ordinances. We then provide some insights into their consequences.

\subsection{The Ambitions of the Reforms: Strengthen Social Dialogue}

The French industrial relations system entered a phase of reforms in 2008, with a change in the rules on trade union representativeness. Since then there have been several laws 
Table 6.3 Main texts reforming social dialogue or policies in which social partners have direct involvement, 2008-20

\begin{tabular}{|c|c|c|}
\hline 2008 & $\begin{array}{l}\text { LOI no. } 2008-789 \text { du } 20 \text { août } 2008 \\
\text { portant rénovation de la démocratie } \\
\text { sociale et réforme du temps de travail }\end{array}$ & New rules for unions' representativeness \\
\hline 2013 & $\begin{array}{l}\text { LOI no. 2013-504 du } 14 \text { juin } 2013 \\
\text { relative à la sécurisation de l'emploi } \\
\text { (based on an inter-sectoral agreement } \\
\text { of } 11 \text { January 2013) }\end{array}$ & $\begin{array}{l}\text { New rules for collective redundancy, } \\
\text { employment maintenance agreements, } \\
\text { individual training account and health } \\
\text { insurance for all employees }\end{array}$ \\
\hline 2014 & $\begin{array}{l}\text { LOI no. } 2014-288 \text { du } 5 \text { mars } 2014 \\
\text { relative à la formation professionnelle, } \\
\text { à l'emploi et à la démocratie sociale }\end{array}$ & $\begin{array}{l}\text { Personal training account (Compte } \\
\text { Personnel de Formation) } \\
\text { Reform of training financing } \\
\text { New rules for employer organization } \\
\text { representativeness }\end{array}$ \\
\hline 2015 & $\begin{array}{l}\text { 'Rebsamen Law' } \\
\text { LOI no. 2015-994 du } 17 \text { août } 2015 \\
\quad \text { relative au dialogue social et à l'emploi }\end{array}$ & $\begin{array}{l}\text { Facultative integration of staff } \\
\text { representation institutions } \\
\text { New representation for very small firms }\end{array}$ \\
\hline 2016 & $\begin{array}{l}\text { 'Loi Travail' } \\
\text { LOI no. 2016-1088 du } 8 \text { août } 2016 \\
\text { relative au travail, à la modernisation } \\
\text { du dialogue social et à la sécurisation } \\
\text { des parcours professionnels }\end{array}$ & $\begin{array}{l}\text { Collective bargaining decentralization } \\
\text { Individual activity account } \\
\text { Youth guarantee }\end{array}$ \\
\hline 2017 & $\begin{array}{l}\text { 'Ordonnances travail' } \\
\text { Ordonnance no. } 2017-1386 \text { du } 22 \\
\text { septembre } 2017 \text { relative à la nouvelle } \\
\text { organisation du dialogue social et } \\
\text { économique dans l'entreprise et } \\
\text { favorisant l'exercice et la valorisation } \\
\text { des responsabilités syndicales }\end{array}$ & $\begin{array}{l}\text { Collective bargaining decentralization } \\
\text { Integration of employee representation } \\
\text { in a single institution (comité social et } \\
\text { economique) } \\
\text { New rules for compensation in case of } \\
\text { abusive lay offs }\end{array}$ \\
\hline 2018 & $\begin{array}{l}\text { LOI no. 2018-771 du } 5 \text { septembre } 2018 \\
\text { pour la liberté de choisir son avenir } \\
\text { professionnel }\end{array}$ & $\begin{array}{l}\text { Further training reform (extension and } \\
\text { reform of the individual account, } \\
\text { new management of financing and } \\
\text { training programmes) }\end{array}$ \\
\hline 2019 & $\begin{array}{l}\text { Unemployment insurance reform } \\
\text { (decree) }\end{array}$ & $\begin{array}{l}\text { Extension to self-employed and people } \\
\text { who resigned (for employees) } \\
\text { Bonus-malus for short-term contracts }\end{array}$ \\
\hline $\begin{array}{l}2020 \\
\quad \text { (planned) }\end{array}$ & $\begin{array}{l}\text { Pension reform (Law, presented to the } \\
\text { Parliament on } 24 \text { January 2020) }\end{array}$ & Universal pension regime \\
\hline
\end{tabular}

(or ordinances) changing the rules on collective bargaining and, more broadly, dialogue between labour and employers. Table 6.3 provides a list of these reforms with brief comments on their content. These reforms are generally aimed at improving the functioning of the French labour market by providing more flexibility at the company level 
(in relation to both workforce adaptation - in case of an economic downturn, for hiring and firing - and collective agreements) and providing more efficient schemes for workers' security (better access to training, and wider unemployment insurance coverage). These are inspired by the flexicurity framework. Most of them (until 2015) were initially based on social dialogue at the national level, which often failed to reach an agreement. These reforms generally consider that social dialogue, if some flexibility is offered, contributes to firms' competitiveness and workers' motivation. More generally it should also increase their capacity to respond to new needs in a changing labour market (workforce adaptation, professional transitions and further training).

With regard to collective bargaining and social dialogue, these reforms include:

- decentralization of collective bargaining to the company level (although the sector retains its competence over important topics, such as occupational classifications and minimum wages, use of atypical labour contracts, gender equality);

- some new rules for union and employer organization representativeness (based on elections and membership) and clarification of their financing;

- a reduction in the number of sectors to clarify sectoral bargaining: the target was set at 200 sectors in the Labour Act 2016, ${ }^{11}$ and President Macron has set a new goal of 50-100 in the medium term. The two criteria for sectoral restructuring are size (sectors should cover at least 5000 workers) and bargaining activity (sectors that have not concluded any agreement for the past ten years have to merge with other sectors);

- new rules for agreement validity at company level, based on the majority principle in firms with a trade union delegate, and on a referendum in other cases, with simplified rules for small firms;

- a change in the rules on employee representation at the company level: creation of the comité social et économique (social and economic committee, CSE) for firms with over 11 employees, replacing previous institutions for staff representation;

- new topics for bargaining: gender equality, tough working conditions, employment of the elderly, teleworking, internal and external flexibility - for instance, the introduction of a collective framework allowing the employer to end labour contracts of willing employees (that framework must be based on a collective agreement signed by trade unions which represent the majority of employees and is also subject to administrative control); and

- creation of an extension committee to examine (on request) opportunities to extend some sectoral agreements (workers' rights and equality, on the one hand, the free competition principle on the other).

In addition to these measures that directly concern social dialogue institutions and processes, many reforms also concerned policy areas in which the social partners play a direct management and administration role. This applies to further training, unemployment insurance and pensions. For further training, the institutional changes are important. The 2018 reform maintains the principle of a compulsory company contribution, but in 2021 this contribution will be collected by the national security administration instead of by specific funds managed by the social partners at the sectoral level (Organisme Paritaire Collecteur Agréé, OPCA). In addition to this centralization of financing, the 
reform also creates a new national institution (France Compétences) that will monitor training institutions (prices and quality). The social partners remain involved at the sectoral level through operating entities (opérateurs de compétence, OPCO) which will be responsible for allocating funding to training in small and medium-sized firms, as well as to apprenticeship training (previously a regional competence). As far as pension reform is concerned, the ambition is to merge different regimes. Therefore, in addition to reforms in collective bargaining and social dialogue, the reforms also involve important changes in the role of the social partners in social and labour market policies.

\subsection{What Impact and Perceptions of these Reforms?}

This subsection is based on two sources: first, the initial results published by the Labour Ordinances committee, which focus on implementation of the latest reforms (2017); second, interviews with social partners and a government representative conducted for this International Labour Organization (ILO) project, in which they were asked about their general perceptions of the reforms over the past decade (see Box 6.1 about interviews).

The social partners on both the employer and the labour side are divided on the importance of the reforms: employers favour the decentralization of collective bargaining and firm-level flexibility, but also demand guarantees at the sectoral level (to avoid unfair competition); reformist trade unions (CFDT, CFTC and CFE-GC) promoted the principle of decentralization, while others defended the traditional hierarchy between national, sectoral and firm level (CGT and FO). These divisions still exist in the reactions to the reforms; however, some converging views also emerged from interviews.

First, the social partners complained about the timing of the reforms, which does not leave them the time to adapt to the new rules and to work on innovative agreements. In practice, a great deal of time is devoted to complying with new obligations and ensuring formal conformity, with no opportunity to work on the contents of the agreements. The implementation of the new CSE is particularly difficult, and actors will not be able to meet the schedule laid down by the ordinances (all CSEs should be elected by the end of 2019). On the employers' side, the complexity of the rules and the number of topics to be considered is also criticized: instead of the simplification of the Labour Code that they have been demanding for years, it imposes new constraints on firms (such as compulsory reporting on gender equality) and some uncertainty about legal interpretation (for instance, regarding sectoral and company competences).

Second, they refer to a failure of social dialogue at national level, which they attribute to the behaviour of the government. Indeed, according to the social partners, the initial ambition of developing social dialogue at the national level that was included in the Labour Act in 2007, has been contradicted by successive governments. Under President Hollande, there was some bargaining at national level and some laws followed national agreements, but the social partners consider that the overall contents of the reforms ran counter to their interests. Finally, the Labour Act of 2016 was implemented without any bargaining or formal consultation. Since the election of President Macron, national bargaining has been controlled by the government, which lays down precise guidelines and makes the ultimate decision, even if that contradicts the inter-sectoral agreement. 
Two examples in particular were mentioned by interviewees. The first is the further training reform (in 2018), which saw the Ministry of Labour calling for a vast reform the day after the social partners had reached an agreement. The second example is the negotiation of unemployment insurance (in 2019) that failed because it was based on very strict guidelines. The more radical unions even take the view that recent governments have lost confidence in social dialogue, and have denied workers the right to contest reforms via protests (by repressing social protests in 2017 or 2020).

Third, the social partners fear a weakening of social dialogue at branch and company levels, contradicting the very aims of the reforms. At company level, the CSE reform may decrease resources for local unions, in relation to number of representatives and number of hours spent on consultation and negotiation. According to the interviewed union representatives, despite some good practices, many firms take a purely cost-orientated view of the reforms, and want to take the opportunity to cut the costs of employee representation. On the workers' side, the CSE does not appear particularly attractive because it involves many responsibilities and expenditure of resources to deal with a variety of issues.

A number of other factors have reduced union power more directly: for example, possibilities for concluding an agreement without the involvement of a trade union official have been substantially extended. At branch level, the content of current negotiations has been imposed by the ongoing reforms: for example, implementation of further training reform, and restructuring and fusion of sectors. The extension of agreements that was a cornerstone of the French industrial relations model and ensured a high coverage rate is also likely to be weakened. This is owing to a number of factors. The Ministry of Labour is trying to slow the extension process and to limit its scope (to take the example of minimum wages, see the case study about sectoral extension on section 6), and there is some uncertainty regarding the role of the new extension committee.

Looking more precisely at the implementation of the Labour Ordinances also shows some substantial difficulties, although impact evaluation will not be possible for a few years (France Stratégie 2018).

A survey of employers and union representatives ${ }^{12}$ revealed that information on the reform was still scarce in June 2019, almost two years after the reform.

More broadly, the take-up of the reform does not seem very high. Most employers have no intention of changing their social dialogue practices in the short term (64 per cent for firms of fewer than 300 employees). Only 13 per cent see the ordinances as an opportunity to develop firm-level collective bargaining.

Finally, many issues have arisen concerning implementation of the new CSE as a body for representing workers. The transition process between the old institutions and the CSE is too slow, although it was accelerating at the end of 2019; according to the same survey, 36 per cent of firms overall are likely to be covered by the reforms by the end of 2019 , but the proportions vary by size (77 per cent of firms with over 50 employees, but only 23 per cent of firms with between 11 and 50 employees).

Union representatives in firms report two main problems with implementing the CSE: a reduction in the number of representatives and delegation hours, ${ }^{13}$ and a lack of training for members of the new committee. A more detailed analysis based on firm case studies confirm a substantial number of difficulties (ORSEU 2019). First, as mentioned in our interviews, many firms consider the CSE to be an opportunity to cut 
costs and therefore the negotiations focus on hours for elected representatives, administrative resources and travel costs, instead of on work methods and training. Second, the integration of all workers' representatives leads to centralization and reduces local worker representation, which used to be ensured by employee delegates. The risk is that the link with employees' local problems will be cut and employees feel that their concerns receive less attention than before. The ordinances have opened up the possibility of specific local representatives (Représentants de Proximité, RP), but this has to be organized by firm-level bargaining and is not compulsory. Third, health and working conditions issues must be covered by the $\mathrm{CSE}^{14}$ (instead of the dedicated CHSCT before the reform). This requires specific competences that not all employee representatives have. There is a danger that security and health issues will have more limited coverage, although the government has introduced compulsory health and safety training for all CSE members. Finally, the ordinances change the conditions offered to employee representatives and trade union delegates: there will be fewer of them, the number of mandates will be fewer (three, except for firms with fewer than 50 employees), and participation in the CSE is likely to be more demanding in relation to time (more topics to deal with). The consequences for people's willingness to take on these mandates are uncertain at this stage.

In contrast with this survey and with the social partner interviews, the government puts forward the development of a new impetus in social dialogue at the company level, around issues such as internal and external flexibility (collective agreements allowing employment adjustments by mutual agreement ${ }^{15}$ or internal adjustments - of wages or working hours - to maintain or increase employment ${ }^{16}$ ), and the conditions of social dialogue (delegation hours beyond the legal level, local representatives, and training for CSE members). At the sectoral level, the transfer of apprenticeship financing from regions to OPCOs is considered a success, as is dynamic bargaining on specific labour contracts.

\section{BOX 6.1 SOURCES FOR THE PROJECT: INTERVIEWS AND LABOUR ORDINANCES EVALUATION COMMITTEE}

Interviews were conducted in October 2019, with national representatives of a number of trade unions (CFDT, CFTC, CGT and FO) and two employers' organizations (CPME and MEDEF). The interviews included questions about perceptions of recent reforms (since 2008), and more precisely about the 2017 ordinances. They also asked interviewees about ways of improving social dialogue and strengthening the social partners, as well as their ongoing actions to support their members and attract new members, including a specific focus on digital platform workers. Interviews were also conducted with members of the administration, to clarify the goals of the reforms, and with some experts (one economist and one labour lawyer).

This information was complemented by presentations and observations of the debates in the ordinance evaluation committee, instituted in September 2017, which includes trade unions and employers' organization representatives, administrations, and academic experts (https://www.strat egie.gouv.fr/evaluation/evaluation-ordonnances-travail, accessed 20 July 2021).

A representative of the government was also interviewed about the contents of the reforms and on social dialogue processes. 
Although the reform is recent and cannot be properly evaluated yet, the interviews and first qualitative information gathered in 2019 show a gap between the ambitions of the reform and the perceptions of the social partners. While the government emphasizes new dynamics for social dialogue and more flexibility at firm and sector levels, the social partners feel weakened by the reform process and by the manner in which tripartite social dialogue has been conducted over recent years. Their capacity to participate in the definition of new rules facing changing labour market conditions seems limited by the prominent role of the state, and by ongoing institutional reforms at the sectoral and company levels.

\section{A MICRO APPROACH TO SOCIAL DIALOGUE: REPRESENTATION, DISCRIMINATION AND UNION ATTRACTIVENESS}

Beyond reforms, it is also important to go down to the micro level and to characterize the situation of employee representatives and union delegates, including the issue of discrimination, which has been at the fore in the recent academic and public debate. Another important issue at that level is the perception of the social partners, and more widely of social dialogue, among workers or the French public. All these factors contribute to trade union attractiveness and their capacity to face the new challenges in the world of work.

In this section, we use recent surveys to address these issues: in addition to ad hoc surveys, the REPONSE ${ }^{17}$ survey is an important source, organized every six years by the Ministry of Labour and dealing with social dialogue and employee representation at the workplace level. In addition to a relatively large sample (4000 different workplaces and 20000 employees), the survey is particularly interesting owing to its structure, which includes three different questionnaires for each workplace: one for employers, one for employees and one for employee representatives.

\subsection{Staff Representatives and Union Delegates at the Firm Level: A Portrait}

According to the REPONSE survey, in 2017, 629,000 employees had at least one mandate as employee representative in French firms; 56 per cent of these representatives are union members and 15 per cent are union officials. ${ }^{18}$

Men are overrepresented among employee representatives, and especially among union officials: 72.9 per cent of union officials are men and only 27.2 per cent are women. Employee representatives tend to be older than employees in general, and tend to have a higher seniority (Table 6.4): 50 per cent of union officials and 37 per cent of employee representatives have been working in their firm for at least 17 years. However, this link between seniority and mandates is not systematic and about one-fifth of representatives have been working in the firm for less than eight years. Also, there is turnover among employee representatives, and 60 per cent of them stated they have had their mandate for four years or less, 24 per cent between five and nine years, and 16 per cent for 10 years or more. This indicates that representing workers, either as a union official or as an elected representative, tends to be temporary.

The survey asked employee representatives and other employees about their attitudes towards unions: union members were asked about the reasons for membership, 
Table 6.4 Employee representatives by seniority, France, 2019 (\%)

Less than one year

Source: REPONSE 2017, DARES, Pignoni (2019).

Table 6.5 Reasons for joining a union, France, 2019 (\%)

\begin{tabular}{lcc}
\hline & $\begin{array}{l}\text { Union members } \\
\text { without a } \\
\text { mandate }\end{array}$ & $\begin{array}{l}\text { Union members with } \\
\text { a mandate (employee } \\
\text { representatives) }\end{array}$ \\
\hline Personal relationships & 51.1 & 50.8 \\
Contact with a trade union delegate & 24.3 & 33.9 \\
Invitation if a colleague & 25.5 & 25.7 \\
Family or friends' advice & 14.9 & 8.1 \\
Following a problem & 27.6 & 22.0 \\
With employer or hierarchy & 25.8 & 23.0 \\
Protection following a personal event & 2.5 & 0.8 \\
Problems in the firm: lay-offs, changes in management, & 1.8 & 1.8 \\
$\quad$ worsened working conditions or social climate & & 14.6 \\
Conviction & 6.9 & 9.7 \\
During a conflict (strike, demonstration) & 11.1 & 2.8 \\
Other circumstances & 2.8 & 0.1 \\
Don't know & 0.6 & \\
\hline
\end{tabular}

Source: REPONSE 2017, DARES, Pignoni (2019).

and non-union members about their reasons for non-membership. The first item was to explain unionization in personal relationships (with union delegates and with other colleagues), and the second was about their experience of problems with the employer or the hierarchy (see Table 6.5). More rarely, attitudes result directly from personal convictions or from an episode of conflict (strike or demonstration). Not being a union member relates, first, to the conviction that there is no need to join a union to defend workers' rights within the firm (41 per cent of respondents) and, second, to the absence of a trade union in the firm (32 per cent of respondents).

Employee representatives have a mixed view of their role and the effectiveness of their actions: 80 per cent think that they do a good job taking workers' needs on board and 56 per cent think that trade unions are the best representatives for employees, but only 37 per cent declare that they are actually able to influence employers' decisions.

\subsection{Discrimination against Union Members and Union Officials}

Being an employee representative (either elected or appointed by a union) is likely to influence a person's circumstances in relation to wage and position. In general, the effect 
can be positive if the employer has a positive perception of their role, but negative if labour representation tends to result in higher wages and lower profits.

In the French case, there is evidence of a negative impact of being a union official, but no real impact of being an elected employee representative (except if he or she is also a union member). Indeed, as in Table 6.6, non-unionized elected representatives are very close to the average of all employees in relation to past promotion or expected risk of losing their job, whereas the situation of union officials appears very distinct, with lower promotion (experienced or expected), higher perceived job insecurity and lower job satisfaction.

These data point to potential discrimination against unionized employee representatives and trade union officials in the French labour market. Although they benefit from specific protection against lay-offs, and although discrimination because of union membership violates the principle of freedom of association, the number of cases related to trade union discrimination in the courts has increased and several studies confirm the existence of diverse forms of discrimination.

A survey conducted by the Défenseur des Droits and the ILO in 2019 (Défenseur des Droits 2019), shows that the problem of discrimination is even wider, and concerns union members in general. Nearly half of union members declare they have experienced some discrimination because of their membership. Discrimination includes the absence of promotion or wage rises, or a decline in working conditions. Declared discrimination seems more frequent in the private than in the public sector. It grows with workers' degree of involvement in union activities, and seems especially important for trade union delegates.

According to the same survey, one-third of the active population thinks that the fear of a wage or career penalty is the first reason workers do not get involved in union activities, and 42 per cent believe that union membership represents a risk of employment or career progression.

Table 6.6 Perceptions of individual employment situation according to union membership and mandate, France, 2019 (\%)

\begin{tabular}{|c|c|c|c|c|}
\hline & $\begin{array}{l}\text { Elected staff } \\
\text { representatives }- \text { not } \\
\text { union members }\end{array}$ & $\begin{array}{l}\text { Elected staff } \\
\text { representatives - } \\
\text { union members }\end{array}$ & $\begin{array}{l}\text { Trade union } \\
\text { officials }\end{array}$ & $\begin{array}{l}\text { All } \\
\text { employees }\end{array}$ \\
\hline $\begin{array}{l}\text { Has been promoted during the } \\
\text { past three years }\end{array}$ & 27.5 & 22.4 & 15.1 & 26.5 \\
\hline $\begin{array}{l}\text { High or very high risk of } \\
\text { losing job in the next } 12 \\
\text { months }\end{array}$ & 12.9 & 19.0 & 21.9 & 12.3 \\
\hline $\begin{array}{l}\text { High or very high chance of } \\
\text { being promoted or getting } \\
\text { a wage increase the next } 12 \\
\text { months }\end{array}$ & 13.2 & 8.7 & 8.6 & 13.0 \\
\hline Satisfied with work in general & 79.9 & 68.8 & 60.2 & 77.2 \\
\hline
\end{tabular}

Source: REPONSE 2017, DARES, Pignoni (2019). 
Research studies have also investigated this issue, using data for 2004 and 2010 (Bourdieu and Breda 2016). They confirm the existence of a wage penalty for union members and for trade union officials. The wage penalty amounts to 3-4 per cent on average for union members, in comparison to non-members of the same age, gender and education level, and rises up to 10 per cent for trade union delegates directly engaged in collective bargaining at the firm level. According to Bourdieu and Breda (2016), such a penalty for trade union officials is a consequence of their specific situation in the firm: their role is to bargain on wages, employment and working conditions, therefore on the distribution of profits, which is very different from other employee representatives, who are engaged in general discussions about the firm's economic and social situation. They find evidence that the wage penalty does not apply to trade union officials who are not engaged in bargaining, and increases above 10 per cent when there is a situation of conflict or a strike at the firm. Therefore, discrimination against trade union officials seems to be an example of strategic discrimination on the part of employers.

Discrimination against union members and officials is likely to reduce unions' attractiveness and therefore their capacity to act autonomously to address important issues, whether traditional (such as wages) or emerging, such as new forms of work or the impact of digitalization on working conditions.

\subsection{Perceptions of Social Partners and Social Dialogue}

Confidence in the social partners and in the institutions of social dialogue matters for the capacity to deal with new issues. Although care must be taken with subjective indicators, there is evidence that French workers' perceptions of the social partners are mixed.

According to the 2017 REPONSE survey (Pignoni 2019), between 30 and 40 per cent of employees have a positive view of trade unions, such as 'trade unions are necessary for employee representation' and 'trade unions provide services to employees', but 32 per cent also agree with the idea that 'trade unions first serve their own interests' and 18 per cent that 'trade unions may be an obstacle to smooth enterprise functioning'.

Opinion surveys (such as BVA 2018 or Harris Interactive 2018) confirm limited confidence in trade unions, although interviewees acknowledge their historical role. Indeed, in the BVA survey only 49 per cent of workers declared confidence in unions when it comes to defending their interests. That proportion is higher among women ( 53 per cent), young people (59 per cent) and public sector employees (54 per cent). However, 78 per cent of employees consider that unions have contributed to social progress, and 73 per cent that high unionization rates, as in the Nordic countries, improve social dialogue.

The situation of employers' organizations in workers' perceptions seems worse: in the Harris Interactive survey, only 29 per cent of employees declared they have a good or rather good opinion of employers' organizations (compared with 45 per cent for trade unions). They are generally associated with words such as profit and market liberalism, although only 7 per cent of employees declare that they understand their role very well (and 38 per cent well). Looking at the future, only a minority of employees would like the social partners to have a bigger role: 18 per cent for employers' organizations and 36 per cent for trade unions.

The low level of confidence in the social partners may be partly related to a lack of knowledge about their role (apart from their contribution to the general political debate, 
which is conflictual in France), but it may also be related to a more general lack of confidence in the intermediary organizations of social and political democracy: confidence in political parties is only a third as high as confidence in trade unions, according to the Ipsos CEVIPOF (2018) 'Social dialogue barometer' (10 per cent confidence for political parties as against 35 per cent for trade unions). By contrast, French employees express high levels of confidence in their direct colleagues ( 80 per cent), in small and mediumsized firms (79 per cent), but also in social security (69 per cent) and employment tribunals (68 per cent). This may seem a paradox as the social partners are directly involved in the administration of these two institutions.

These results more generally are related to adverse perceptions of the quality of dialogue between employers and employees and social relations at the workplace. International surveys provide evidence that perceptions in France are particularly bad in comparison with other developed countries. France seems to be the country with the lowest quality relationships between employers and employees (Ferracci and Guyot 2015). According to the latest European Working Conditions Survey (2015), ${ }^{19}$ the level of fairness, cooperation and trust perceived by French employees is one of the lowest in Europe.

However, other surveys that include some more objective questions about the work context provide a more optimistic view. For instance, according to the French working conditions surveys, more than 80 per cent of employees declare that they can get some help from their colleagues (always or almost always) and 66 per cent that they can get some help from their managers hierarchy (Figure 6.3). However, the trend over time (since 1998) is positive for all indicators and all groups. In the same vein, according to the same survey, 78 per cent agree that their direct superiors pay attention to what they say, and two-thirds of employees consider that they also care about their health (Beque et al. 2019).

Therefore, everyday social relationships at work might be better than general indicators of trust or confidence tend to show. As far as the social partners are concerned, there is a clear need for better information about their role at the firm level, and the discrimination issue must be addressed as it represents a barrier to trade union participation.

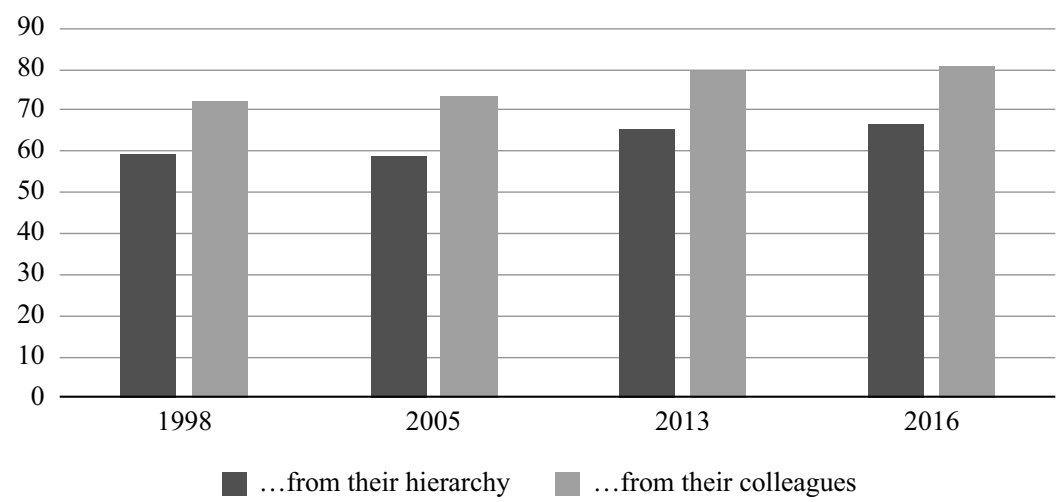

Source: Dares-Drees-DGAFP-Insee, enquêtes Conditions de travail, Beque et al. (2019).

Figure 6.3 Proportion of employees who can get support for difficult tasks ... 


\section{FUTURE OF SOCIAL DIALOGUE IN A NEW ECONOMIC AND SOCIAL CONTEXT: DEBATES AND PERSPECTIVES}

In the public debate and in our interviews, three main topics have emerged for the future of social dialogue. The first issue concerns how to strengthen the social partners and reinforce their legitimacy and autonomy in a new context of social dialogue in which the enterprise level has become more important. The second concerns the levels of social dialogue, especially the role of the national or sectoral level in the new context. The third issue relates to the heterogeneity and coverage of small firms, or new forms of work.

\subsection{Increasing Membership through the Development of New Services?}

Existing proposals in the French debate have focused on two main directions (see Ferracci and Guyot 2015 for a synthesis). The first is to raise union membership either by obligation, or by incentive mechanisms. Obligation is not part of the French tradition and would be contrary to the Constitution. Incentive mechanisms include measures such as the chèque syndical (trade union voucher), which would provide every employee with a voucher they can use to pay for their union membership. Incentives can also come from the development of new union services for their members. The second direction for reform is more indirect, and assumes that there is a link between the outcomes of collective bargaining and participation. According to this view, the participation of French employees is low because they know that the main outcomes on the French labour market result from legislation or from mechanisms controlled by the government (such as extension), not from social dialogue. One solution could be to link union membership and coverage by collective agreements or by unemployment insurance more directly, as is the case in some other countries. However, this solution runs counter to the French legal system. Also, the minimum wage, wage levels and trends are largely influenced by the government, and margins for adaptation at sector and firm levels are limited. This perspective would lead to the recommendation of more labour market deregulation as a way to promote autonomy of collective bargaining.

According to our interviews, trade unions do not share these views and do not wish to see a radical change in the institutions and functioning of collective bargaining. They are convinced that the social partners have a more general role to play, and contribute to general social interest. However, the low membership and the low participation of younger workers are matters of worry for unions as they compromise their autonomy and legitimacy, and urge them to develop new forms of support and services for their members. All interviews confirm this will to develop new forms of support for their members, especially through digital services and online communities, as well as attempts to reach new publics, such as digital platform workers. As these workers are generally far from traditional unions and do not work in a given location, this requires specific tools: an important goal is to achieve a work community, as mentioned by one interviewee. Developing new services (such as health insurance or holidays and leisure activities) also appears an option to maintain or develop unionization for employees (especially in small firms), as well as for platform workers. Services can also be directly related to job search or career: trade unions may also offer help in writing a résumé or preparing for an 
important interview, or with some career guidance. Finally, all trade unions and employers' organizations have developed practical guides to help their members adapt to new rules at the firm level, for instance, in the implementation of the PSE.

\subsection{Revitalizing the National Level to Deal with Important Topics in the New World of Work?}

Recent reforms have given more importance to company-level collective bargaining. However, the French system of collective bargaining remains a multi-level system. The national level has functioned less well over recent years. In addition to the criticisms of government attitudes, both employers' organizations and trade unions consider it important to maintain the national level of bargaining. The employers also perceive this as a way of avoiding unfair competition between sectors. Some have suggested that the social partners should focus on specific topics to work on and bring to the fore in the public debate. Topics mentioned in the interviews included digitalization and the right to disconnect, new forms of employment, labour contracts, quality of working life, and the status of managers. One trade union also proposed the creation of a specific institution for inter-sectoral social dialogue, which would also include participation of associations and non-governmental organizations (NGOs), and therefore contribute to social democracy. That institution would itself choose the topics for dialogue, but could also react to demands from government. The social partners are also unanimous about the importance of the sectoral level and the need to maintain extension mechanisms, with some debate about the interpretation of sectoral competences (see case study in section 6). Finally, one trade union also stressed the importance of the local level for social dialogue and the need to elucidate rules for representativeness at that level.

\subsection{Small Firms and New Forms of Work Need More Attention}

The reforms have generally failed to develop social dialogue in small firms, and there are strong doubts about the effectiveness of the ordinances in achieving this goal. The use of referendums by employers will probably remain limited, as this would generally lead to a deterioration of the social climate, which is not what small businesses are looking for. However, it is very difficult for employees to engage in discussions and bargaining as they are not protected or trained for that purpose. The solution of employees mandated by unions seems interesting, but it has never been developed. In this context, solutions are not straightforward and the institutionalization of social dialogue in small firms does not seem likely. However, employees still need to be protected (which calls for maintaining extension at the sectoral level) and could be interested in services provided by trade unions (while employers could be interested in services offered by employers' organizations).

In relation to new forms of work (especially platform work), employers' organizations are generally in favour of some regulation to avoid competition with more traditional firms. Trade unions have taken the needs of these new publics on board and have started to develop specific services (see case study in section 7). 


\section{CASE STUDY 1: EXTENSION OF COLLECTIVE AGREEMENTS - A PROCESS UNDER PRESSURE DESPITE SOCIAL PARTNER SUPPORT?}

Administrative extension plays an important role in the French industrial relations system, and contributes to the very high level of coverage by collective agreements (almost 100 per cent) and to wage dynamics (together with the legal minimum wage). Sectors are responsible for setting the level of minimum wages, that is, minimum wages for different occupational levels in the sector. Although the recent reforms have maintained the extension process, it seems to have been under pressure since the 2017 Labour Ordinances, which created an expert commission to provide advice on extension in some cases and, more generally, changed the competences of the sector. In this case study, we present the process and its outcomes, focusing on the recent debates and tensions around it. The case study is based on administrative reports on collective bargaining, providing information on extension and comments by social partners, and on interviews (see Box 6.1).

\subsection{A Process Involving the Social Partners}

Although the Ministry of Labour takes the final decision on extension, it is the result of a process that directly involves the social partners.

Extension is, first, conditional on the validity of the sectoral agreement, which must be signed by one or several trade unions representing at least 30 per cent of votes in the first round of employee elections. There is also a right for trade unions or employers' organizations to oppose extension. ${ }^{20}$

The process is as follows:

- One or more trade unions that signed the collective agreement must ask for its extension.

- The corresponding agreement is examined by the administration to check its validity and legality.

- The National Committee for Collective Bargaining (Comité National de la Négociation Collective, CNNC, which includes social partner and administration representatives) is consulted and gives advice on extension.

- The Ministry of Labour extends (or not) the agreement and publishes it.

In addition to the issue of legality, the Ministry of Labour can refuse extension if it is contrary to the general interest or to the goals of the labour market and social policy. For the same reasons, it can also extend the agreement partially, with some exclusions. For instance, the Ministry of Labour refused to extend a 2006 agreement that enabled employers in some service activities to force employees to retire before the age of 65 . This would have contradicted the general goals of employment policy and the desire of the government to increase employment rates among older workers.

In practice, there are two different procedures for extension: the standard procedure and the accelerated procedure for minimum wage agreements. Despite some variations, depending on sectoral bargaining (partly related to legal obligations), the number of 
Table 6.7 Number of extended sectoral agreements per year, France, 2009-18

\begin{tabular}{lrrrrrrrrrr}
\hline & 2009 & 2010 & 2011 & 2012 & 2013 & 2014 & 2015 & 2016 & 2017 & 2018 \\
\hline Accelerated procedure & 432 & 359 & 472 & 482 & 407 & 401 & 266 & 376 & 406 & 406 \\
Standard procedure & 644 & 636 & 598 & 579 & 441 & 498 & 543 & 524 & 481 & 645 \\
Total & 1076 & 995 & 1070 & 1061 & 848 & 899 & 809 & 900 & 887 & 1051 \\
\hline
\end{tabular}

Source: $\quad$ DGT (2019).

extended agreements in 2018 was very close to its level in 2009, at around 1000 per year (Table 6.7). In 2018, 77 agreements were extended, with some exclusions (74 in 2017).

Although extension is almost general in the different sectors of the economy, a limited share of agreements ( 5 per cent) are not extended since the trade unions do not instigate it. Between 2014 and 2016, these cases belonged mainly to sectors in which coverage by employers' organizations is high, with generally bigger firms with better employment conditions. The sectors in which extension has an important impact (that is, those in which employer organization membership is low) include small firms, mostly in the service sector, employing more young people and women, and with less favourable employment conditions (Langevin 2018).

\subsection{Debates around Extension and Recent Tensions}

In the academic literature, ${ }^{21}$ as well as in social partners' discourse ${ }^{22}$ extension is recognized as a way of equalizing workers' employment conditions, but also of harmonizing the conditions of competition between firms in a given sector. It also enables firms that have limited means to devote to social dialogue (especially smaller firms) to benefit from interesting tools developed at the sectoral level. Nevertheless, extension may also create unfair competition if the employers signing the agreements do not take into account the situation of firms that are not affiliated to employers' organizations or if some particular firm categories (for instance, larger firms) have more bargaining power.

In this context, to avoid potential harm, France was subject to several recommendations by the OECD in 2017. These recommendations included: the introduction of more restrictive criteria for the validity of sectoral agreements, including conditions of the representativeness of employers' organizations; the creation of an independent expert committee that would evaluate the economic and social effects of extensions; the differentiation of collective agreements in accordance with firm characteristics to better adapt to the specific conditions of small firms, or to some regional characteristics; and opening up possibilities for opting out, even for firms belonging to organizations that signed the agreement. In the French debate, some mainstream labour economists have recommended going further and ceasing the extension procedure, which they consider has a negative impact on employment. ${ }^{23}$ The option retained by the government was closer to that of the OECD, and the 2017 Labour Ordinances actually introduced obligations for sectoral agreements to include specific clauses for small firms, and created a new expert committee in charge of extension. The committee can be consulted at the request of the social partners or of the Ministry of Labour. Another critique by social partners is that 
Table 6.8 Average time spent by the Ministry of Labour examining extension cases, France, 2011-18 (number of days)

\begin{tabular}{lrrrrrrrr}
\hline & 2011 & 2012 & 2013 & 2014 & 2015 & 2016 & 2017 & 2018 \\
\hline Wage agreements & 59 & 81 & 73 & 90 & 106 & 69 & 86 & 179 \\
Other agreements & 165 & 184 & 180 & 152 & 158 & 153 & 166 & 201 \\
Global & 107 & 130 & 122 & 116 & 138 & 107 & 122 & 190 \\
\hline
\end{tabular}

Source: $\quad$ DGT (2019).

the time taken by the Ministry of Labour to examine extensions rose by more than 50 per cent between 2017 and 2018 (Table 6.8).

What have been the consequences of these new rules for extension? At the time of writing, it is too early to provide a proper evaluation of this reform, but recent trends raise two important issues.

First, there is significant uncertainty around the new expert committee. Its broad composition $^{24}$ shows a will to achieve a balance between the principle of competition and workers' protection, but several trade unions have questioned the intentions of the government and see the committee as a way of reducing the extension rate (especially the CGT and the $\mathrm{FO}^{25}$ ), or at least to slow down the process. Also, the government's choice to nominate an economist who has signed several texts asking for the end of sectoral extension has been perceived as a provocation by some trade unions, or as a sign that the government wants to weaken extension. The committee has been working on two main issues: the definition of potential criteria of extension, in respect of hierarchical wage agreements, and a practical case concerning the sector of cash transportation.

Second, the Labour Ordinances of 2017 have direct and indirect consequences on extension. They laid down that sectoral agreements should include clauses for small firms, which the administration has to check. Also, the Labour Ministry also needs to elucidate the competences of the sector, especially in respect of wages. According to the new architecture of social dialogue, hierarchical wages are defined at the sectoral level, but premiums and bonuses belong to firm-level bargaining. As a consequence, although the case of flexible bonuses is clear, there is some ambiguity concerning some fixed premiums that in practice belong to workers' regular incomes. Recent decisions (spring 2019) by the Ministry of Labour to exclude some extension clauses concerning these premiums has been interpreted by trade unions and employers at the sectoral level as expressing a restrictive view of sectoral competences. ${ }^{26}$

Another criticism of the social partners is that the time taken by the Ministry to examine extensions rose by more than 50 per cent between 2017 and 2018. The labour administration justifies this by the need to implement the reform and to adapt the criteria, whereas trade unions see only delays that they consider detrimental to workers' rights (DGT 201927). 


\section{CASE STUDY 2: SOCIAL DIALOGUE IN THE DIGITAL ECONOMY: INNOVATIVE AGREEMENTS AND PERSPECTIVES FOR PLATFORM WORKERS}

Two main issues related to digitalization and its consequences for workers exist in the French debate: how to promote innovation in the use of digital technologies, and how to include platform workers and new forms of work in social dialogue and social protection?

\subsection{The Right to Disconnect and Collective Bargaining on Using New Technologies}

Digitalization has many consequences for the content of work and employment relationships. It creates new opportunities (such as the possibility to work from home, and new forms of collaboration), but it also raises concerns in relation to working hours and frontiers between working life and private/family life. In France, both social partners and the government have raised the topic and the law has established a number of principles. More precisely, the Labour Act 2016 introduced the right to disconnect (droit à la déconnexion) to protect leisure and vacation time and work-life balance. In practice, collective bargaining to define the implementation of this right within the firm is compulsory for all firms that have a trade union official. In the absence of an agreement, the employer has to enforce the right by defining a charter that includes regulation tools, as well as training in the use of digital tools. In this context, some interesting agreements have been signed in large companies.

Orange was one of the first companies to propose a comprehensive view of the consequences of digital transformation in a specific agreement, signed by three representative trade unions (accord transformation numérique, digital transformation agreement, 27 September 2016). ${ }^{28}$ The general view promoted by the agreement is that the consequences of digital transformation for activities, competences and work vary by occupation and skill, and according to human resource policies. It includes both risks (inequalities arising in connection with digital technologies, poorer work-life balance and use of personal data) and opportunities (new management and working methods, including more collaborative methods, and new organization of working spaces). The tools developed to face these transformations include:

- training to provide digital skills to all (digital academy on computer and smartphone), digital skills self-assessment tool and specific training for managers;

- recommendations to respect the right to disconnect and time outside working time (use of emails, with managers and executives setting an example);

- measures for individual data protection; and

- internal prospective studies - analysis of existing uses of digital technologies and risks associated with excessive use, and a 'work lab' to identify new practices in work organization and work practices.

Several other agreements are mentioned in the reports on collective bargaining. The Airbus agreement (signed on 17 October 2018) stresses that management needs to set an example and recommends that the distinction between working hours and leisure 
time must be respected. The Saint-Gobain agreement (17 May 2018) provides for a satisfaction survey to identify the impact of digital tools on employees. The agreement at Alstom Transport (17 May 2018) lays down a right for workers to report problematic uses of digital tools to their superiors $(\mathrm{N}+2)$ or to human resources, and notes that they can contact an employee representative on these issues.

The Labour Ordinances of 2017 followed up on the consequences of digitalization for work by facilitating teleworking. According to the reformed Labour Code, teleworking can be introduced without changes in an employee's labour contract, either if they explicitly agree or through a collective agreement (or a charter elaborated by the employer in the absence of an agreement). In practice, this has become an important topic for company-level bargaining: many agreements define quotas of teleworking days, or specific situations in which teleworking can be proposed to workers or extended (disability, or temporary personal difficulties, such as the sickness of a relative) (DGT 2019).

\subsection{The Representation of Platform Workers}

Platform workers have increasingly come to the fore among the concerns of the social partners. Following a first initiative by UNSA in 2015 to affiliate non-salaried drivers, all the representative unions are now involved in organizing platform workers. The CFDT has launched a 'union' platform providing services such as accounting, civil and professional insurance, complementary health insurance and legal advice (for a fee amounting to 1 per cent of a self-employed person's turnover). Several union initiatives focus on minimum tariffs (Chagny 2019).

In addition to the initiatives taken by individual trade unions to cover platform workers, a debate has emerged on ways to develop social dialogue for them. That debate has taken innovative forms, based on a participatory network, including actors of the collaborative economy and the digital world, the cooperative world, trade unionists, researchers, experts and other public actors. This network, named 'sharers and workers', ${ }^{29}$ was launched in 2017 and more than 700 stakeholders have participated in sharers and workers days since 2016 to reflect collectively on the future of work and social relations (Chagny 2019).

Representation of platform workers is a key issue for developing social dialogue, but it is also very difficult to implement. According to the sharers and workers network (Chagny et al. 2017), one solution would be to develop representation at the sectoral or territorial level (for instance, département level). Elections could be organized, with workers voting for an organization rather than for a person - and representative unions would then nominate their representatives at the sectoral or local level. On the employer side, the issue of representativity is more difficult to solve and must be discussed further.

Debates also focus on complementary health insurance for these workers. Given the heterogeneity of statuses and situations (part-time with another job, students, or full-time workers) some flexibility is needed in the supply of complementary health insurance. Trade unions can play a role in providing these services, and sectors may also propose some health vouchers for occasional workers. In a broader perspective, health insurance could be linked to a personal activity account, which should include all individual rights. 
Finally, it is important to notice that the legal context is still evolving on the issue of platform workers' status: in March 2020 the Supreme Court (Cour de Cassation) took the view that the relationship between Uber and its drivers involved subordination and therefore corresponded to a labour contract, not a service relationship. This decision will give more power to drivers as well as to the unions representing them to bargain on status issues.

\section{CONCLUSIONS}

Social dialogue in France has evolved over the past ten years, to include more flexibility at the company level and to deal with new issues, including digitalization. Some interesting outcomes might be mentioned, such as the development of agreements dealing with the right to disconnect, or teleworking. There are interesting efforts to include and represent platform workers, even though nothing has been transposed into law yet. At the national level, inter-sectoral agreements and related laws have addressed the consequences of the diffusion of new forms of employment: regulation of part-time work and temporary contracts, redefinition of training rights (on a more individual basis), and unemployment insurance.

However, although the social partners have participated in this process, the state has taken the lead on many issues and the space for autonomous social dialogue has shrunk. The trend towards more decentralized collective bargaining creates a number of opportunities to develop new bargaining dynamics at the firm level, and has led to the development of some innovative company-level agreements. However, the reduction in the number of employee representatives, as well as the introduction of new possibilities to conclude agreements without unions (in small firms) does not help to reinforce the social partners at the company level. The extension process, which tends to be consensual among employer organizations and unions, remains a cornerstone of French industrial relations, leading to a very high coverage rate, although it seems to be coming under pressure, giving rise to some uncertainty for the future evolution of coverage. Finally, despite some common criticisms of successive governments and reforms, the trade unions still appear divided, which tends to reduce both their bargaining power and their attractiveness.

In this context of significant challenges for the French social partners, the issue of the attractiveness of trade unions to workers (and their acceptability to employers), as well as their public perception, would appear to be a key issue for the future. In that respect, it is imperative that trade unions and employers' organizations, at both national and local or company levels, address the new questions arising in a changing work environment (technological change and transitions, working conditions in a digital environment, and new forms of employment). To that end, they should further develop training for their members, expertise and cooperation with civil society. Also, based on this diagnosis, attractiveness could be enhanced and higher membership achieved by developing new concrete services for workers and employers. 


\section{ABBREVIATIONS}

ACEMO: Activité et Conditions d'Emploi de la Main d'Oeuvre

CE: Comité d'Entreprise

CFDT: $\quad$ Confédération Française Démocratique du Travail

CFE-CGC: Confédération Française de l'encadrement - Confédération Générale des Cadres

CFTC: $\quad$ Confédération Française des Travailleurs Chrétiens

CGPME: Confédération Générale des Petites et Moyennes Entreprises

CGT: $\quad$ Confédération Générale du Travail

CHSCT: Comité d'Hygiène, de Sécurité et des Conditions de Travail

CPF: Compte Personnel de Formation

CPME: $\quad$ Confédération des Petites et Moyennes Entreprises

CSE: $\quad$ Comité Social et Economique

FO: $\quad$ Force Ouvrière

MEDEF: Mouvement Des Entreprises de France

OPCA: Organisme Paritaire Collecteur Agréé

OPCO: Opérateur de Compétences

REPONSE: Relations professionnelles et négociations d'entreprise

RP: Représentants de Proximité

Solidaires: Union syndicale Solidaires

U2P: $\quad$ Union des entreprises de proximité

UNAPL: Union Nationale de Professions Libérales

UNSA: Union Nationale des Syndicats Autonomes

UPA: Union Professionnelle Artisanale

\section{NOTES}

1. For a synthetic presentation of institutions see Gazier and Petit (2019).

2. A list of abbreviations is provided at the end of the chapter.

3. CPME specializes in small and medium-sized businesses, and U2P in craft and small retail businesses.

4. See Table 6.3.

5. The figure is based on a working conditions survey and on the French module of EU-SILC. However, there has been some debate about this estimation, as it does not seem consistent with other sources (in particular, members registered by the unions themselves) and might overestimate the unionization rate. See Andolfatto and Labbé (2019).

6. All the figures in this paragraph are based on Pignoni (2016), and updated statistics published on the Ministry of Labour website (https://dares.travail-emploi.gouv.fr/donnees/la-syndicalisation, accessed 20 July 2021), using the French working conditions survey, in which there is a question about unions.

7. In firms with over 50 employees, the employer cannot oppose the appointment of trade union delegates.

8. The employer has been able to introduce this type of single institution in companies of 300 employees or more since 2015 .

9. See Table 6.3.

10. Accord National Interprofessionnel sécurisation de l'emploi et des parcours professionnels, National Intersectoral Agreement on Employment Security and Careers, 11 January 2013.

11. Which should be realized in 2021.

12. See https://www.strategie.gouv.fr/actualites/comite-devaluation-ordonnances-travail-reunion-pleniere-22juin-2018 (accessed 20 July 2021). 
13. Even if the ordinances set an equivalent number of hours (fewer representatives, but more hours for each representative). However, some large firms had extra hours (beyond that which was laid down in the law) and cut them.

14. A specific CSE commission will be devoted to these issues in bigger firms.

15. Ruptures conventionnelles collectives (conventional collective dismissals).

16. Accords de performance collective (collective performance agreements).

17. Relations professionnelles et négociations d'entreprise (Industrial relations and firm-level collective bargaining).

18. All figures in this paragraph and the next, unless another reference is provided, come from REPONSE 2017 (Pignoni 2019).

19. Accessed 20 July 2021 at https://www.eurofound.europa.eu/data/european-working-conditions-survey.

20. To exercise that right of opposition, the trade unions must represent at least 50 per cent of votes in staff elections at the sectoral level. Employers' organizations must also represent a majority of employers in the sector.

21. For a synthesis see Gazier and Petit (2019).

22. This was the case in the interviews conducted for the project, see section 3 in this chapter.

23. See https://www.lesechos.fr/2017/06/halte-a-lextension-des-conventions-de-branche-174530 (20 July 2021), and Cahuc and Zylberberg (2017).

24. Five members comprising three economists (among them the Vice-President of the Competition Authority), one lawyer, one statistician member of the administration.

25. See their comments in the annual report on collective bargaining (DGT 2019).

26. Although it is formally in accordance to the law. Sources are interviews and Didry (2020).

27. See, for instance, the comments by the CGT. This was also mentioned by the members of trade unions interviewed for the project.

28. See also Jolly and Naboulet (2017).

29. See https://www.sharersandworkers.net/ (accessed 20 July 2021).

\section{BIBLIOGRAPHY}

Andolfatto, D. and D. Labbé (2019), 'Combien de syndiqués en France?', Les études sociales et syndicales, Institut Supérieur du Travail, accessed 20 July 2021 at https://www.istravail.com/ actualites-etudes/les-etudes-sociales-et-syndicales/11226-combien-de-syndiqu $\% \mathrm{C} 3 \% \mathrm{~A} 9 \mathrm{~s}$-en-fran ce.html.

Beque, M., A. Kingsada and A. Mauroux (2019), 'Les rapports sociaux au travail', Synthèse stats, no. 27.

Bourdieu, J. and T. Breda (2016), 'Des délégués syndicaux sous-payés: une situation de discrimination stratégique? Une analyse économétrique à partir de l'enquête REPONSE de 2010', Travail et Emploi, 1 (145), 31-58.

BVA (2018), 'Les salariés et le syndicalisme', accessed 20 July $2021 \mathrm{http} / /$ syndicollectif.fr/wpcontent/uploads/2018/07/BVA-Club-m\%C3\%A9dia-RH-Les-salari\%C3\%A9s-et-le-syndicalismejuin-20181.pdf.

Cahuc, P. and A. Zylberberg (2017), 'La réforme n'a pas encore eu lieu', Commentaires, 4 (160), 815.

Centre de recherches politiques de Sciences Po (CEVIPOF) (2018), 'Social dialogue barometer', accessed 20 July 2021 at http://www.sciencespo.fr/cevipof/fr/content/barometre-du-dialoguesocial.

Chagny, O. (2019), 'Country report: France', 'Don't GIG Up' project state of the art report, Document de travail IRES, no. 2.

Chagny, O., C. Jolly, A. Naboulet, N. Amar, and L.-C. Viossat (2017), 'Dialogue social et protection sociale dans l'économie des plateformes: enjeux et pistes d'action', Note de synthèse France Stratégie, November.

Conseil d'orientation pour l'emploi (COE) (2017), 'Automatisation, numérisation et emploi', accessed 20 July 2021 at http://www.coe.gouv.fr/Detail-Nouveaute.html\%3Fid_article=1347. html. 
Courtioux, P. and C. Erhel (2018), 'Social dialogue in France under pressure: can worker security be achieved in a context of increasing job flexibility?', in D. Vaughan-Whitehead (ed.), Reducing Inequalities in Europe How Industrial Relations and Labour Policies Can Close the Gap, Cheltenham, UK and Northampton, MA, USA: Edward Elgar, pp. 168-207.

Défenseur des Droits (2019), '12e baromètre de la perception des discriminations dans l'emploi', Études \& Résultats working paper, September.

Direction Générale du Travail (DGT) (2019), La négociation collective en 2018, Paris: Ministère du Travail.

Didry, C. (2020), 'De l'entreprise à l'établissement? Retour sur les enjeux du salaire minimum hiérarchique dans les conventions collectives de branche', Le Droit Ouvrier, no. 859, 1-6.

Ferracci, M. and F. Guyot (2015), Dialogue social et performance économique, Paris: Presses de Sciences Po.

France Stratégie (2018), 'Évaluation des ordonnances relatives au dialogue social et aux relations de travail', Note d'étape sur les travaux du comité d'évaluation, France Stratégie, Paris.

Gazier, B. and H. Petit (2019), Economie du travail et de l'emploi, Paris: La Découverte.

Harris Interactive (2018), 'Le regard des français sur les organisations patronales', accessed 20 July 2021 at https://harris-interactive.fr/opinion_polls/le-regard-des-francais-sur-les-organi sations-patronales/.

Jolly, C. and A. Naboulet (2017), 'Mutations digitales et dialogue social', Note de synthèse France Stratégie, November, France Stratégie, Paris.

Langevin, G. (2018), 'Les extensions des accords de branche: quels sont les entreprises et les salariés concernés?', DARES Analyses, no. 53, Ministry of Labour, Paris.

Langevin, G. (2019), 'Adhésion aux organisations patronales: une mesure de la couverture patronale', Document d'études DARES, no. 228, Ministry of Labour, Paris.

Organisation for Economic Co-operation and Development (OECD) (2017), 'Les extensions administratives des accords de branche en France: effets et pistes de réformes', accessed 20 July 2021 at http://www.oecd.org/fr/emploi/extensions-administratives-des-accords-de-branche-enFrance.pdf.

ORSEU (2019), 'Appropriation et mise en œuvre des ordonnances du 22 septembre 2017 réformant le droit du travail, étude de terrain qualitative', report for the Ministry of Labour, in the framework of the Labour Ordinances Evaluation Committee, Lille.

Pignoni, M.-T. (2016), 'La syndicalisation en France', DARES Analyses, no. 25, Paris.

Pignoni, M.-T. (2019), 'Les représentants du personnel dans l'entreprise: des salariés comme les autres?', DARES Analyses, no. 2, Paris.

Romans, F. (2018), 'Les relations professionnelles en 2017: un panorama contrasté du dialogue social dans les établissements?', DARES Analyses, no. 15, Paris.

Tall, A. (2018), 'Le dialogue social dans les TPE en 2016', DARES Résultats, no. 20, Paris. 